\title{
The impact of surgical site infection—a cost analysis
}

\author{
Rahel M. Strobel ${ }^{1} \cdot$ Marja Leonhardt $^{2} \cdot$ Frank Förster $^{3} \cdot$ Konrad Neumann $^{4} \cdot$ Leonard A. Lobbes $^{1} \cdot$ Claudia Seifarth $^{1}$. \\ Lucas D. Lee ${ }^{1}$. Christian H. W. Schineis ${ }^{1} \cdot$ Carsten Kamphues $^{1} \cdot$ Benjamin Weixler $^{1} \cdot$ Martin E. Kreis ${ }^{1}$. \\ Johannes C. Lauscher ${ }^{1}$
}

Received: 3 February 2021 / Accepted: 29 September 2021 / Published online: 14 October 2021

(c) The Author(s) 2021

\begin{abstract}
Purpose Surgical site infection (SSI) occurs in up to $25 \%$ of patients after elective laparotomy. We aimed to determine the effect of SSI on healthcare costs and patients' quality of life.

Methods In this post hoc analysis based on the RECIPE trial, we studied a 30-day postoperative outcome of SSI in a singlecenter, prospective randomized controlled trial comparing subcutaneous wound irrigation with $0.04 \%$ polyhexanide to $0.9 \%$ saline after elective laparotomy. Total medical costs were analyzed accurately per patient with the tool of our corporate controlling team which is based on diagnosis-related groups in Germany.

Results Between November 2015 and May 2018, 456 patients were recruited. The overall rate of SSI was 28.2\%. Overall costs of inpatient treatment were higher in the group with SSI: median $16.685 € ; 19.703$ USD (IQR 21.638 €; 25.552 USD) vs. median $11.235 € ; 13.276$ USD (IQR $11.564 € ; 13.656$ USD); $p<0.001$. There was a difference in surgery costs (median $6.664 € ; 7.870$ USD with SSI vs. median $5.040 € ; 5.952$ USD without SSI; $p=0.001$ ) and costs on the surgical ward (median $8.404 € ; 9.924$ USD with SSI vs. median $4.690 € ; 5.538$ USD without SSI; $p<0.001)$. Patients with SSI were less satisfied with the cosmetic result ( $4.3 \%$ vs. $16.2 \% ; p<0.001)$. Overall costs for patients who were irrigated with saline were median $12.056 € ; 14.237$ USD vs. median $12.793 € ; 15.107$ USD in the polyhexanide group $(p=0.52)$.

Conclusion SSI after elective laparotomy increased hospital costs substantially. This is an additional reason why the prevention of SSI is important. Overall costs for intraoperative wound irrigation with saline were comparable with polyhexanide.
\end{abstract}

Keywords Surgical site infection $\cdot$ Cost analysis · Visceral surgery $\cdot$ Laparotomy

\section{Introduction}

Rahel M. Strobel

rahel.strobel@charite.de

1 Department of General, Visceral and Vascular Surgery, Charité Campus Benjamin Franklin, Hindenburgdamm 30, 12203 Berlin, Germany

2 Innlandet Hospital Trust, Norwegian National Advisory Unit On Concurrent Substance Abuse and Mental Health Disorders, Brumunddal, Norway

3 Corporate Controlling, Charité Campus Mitte, Charitéplatz 2, 10117 Berlin, Germany

4 Institute of Biometry and Clinical Epidemiology, Charité Universitätsmedizin Berlin, Freie Universität Berlin, Humboldt-Universität Zu Berlin and Berlin Institute of Health, Charitéplatz 1, 10117 Berlin and Berlin Institute of Health (BIH), Anna-Louisa-Karsch Str. 2, 10178 Berlin, Germany
Surgical site infection (SSI) is a common complication of abdominal surgery. Previous studies showed SSI rates after visceral surgery as high as $20 \%[1,2]$. SSI results in up to one million additional days of hospitalization per year and considerable healthcare costs in Germany [3]. In the USA, attributable costs for SSI vary between $\$ 10.443$ and $\$ 25.546$ per infection $[4,5]$. Over the years, early discharge from the hospital became one goal of medical care. SSI is a huge burden for the patient and has a relevant impact on the patient's satisfaction with healthcare. There is a lack of studies concerning the quality of life of patients with SSI in abdominal surgery. In the RECIPE trial (Reduction of postoperative wound infections by antiseptica?) conducted in the Department of General, Visceral and Vascular Surgery of the Charité - Campus Benjamin Franklin Berlin, we could show that intraoperative subcutaneous wound irrigation with 
polyhexanide reduces SSI in elective laparotomies compared to wound irrigation with saline [6].

The objective of this post hoc analysis of the RECIPE trial was to determine the impact of SSI on inpatient costs and patients' postoperative outcome. We compared the costs of patients receiving intraoperative wound irrigation with saline and polyhexanide.

\section{Materials and methods}

\section{Trial oversight}

Data presented in this manuscript are based on the RECIPE trial. The RECIPE trial was a single-center, randomized controlled, prospective trial with two treatment groups comparing intraoperative subcutaneous wound irrigation with $250 \mathrm{ml}$ of $0.04 \%$ polyhexanide solution (Serasept2@, Serag-Wiessner, Naila, Germany) to $250 \mathrm{ml}$ of $0.9 \%$ saline in elective open or laparoscopically assisted abdominal surgery. The primary outcome data - rate of SSI 30 days postoperatively — was published previously [6]. Here, we report a post hoc analysis of this prospectively collected cohort analyzing the impact of SSI on inpatient costs and 30-day postoperative outcome.
The RECIPE trial was an investigator-initiated Medicinal Products Act trial. The study protocol was approved by the State Office for Health and Social Affairs Berlin (Study Protocol code RECIPE2014; EudraCT number: 2014-001,55122) and the Federal Institute for Drugs and Medical Devices. The trial was conducted in accordance with the ethical principles of the Declaration of Helsinki and the principles of Good Clinical Practice (ICH-GCP E6) [7]. This trial is registered at http://www.ClinicalTrials.gov (ID: NCT04055233).

\section{Patients and intervention}

Patients 18 years or older, capable to give informed consent, and undergoing elective open or laparoscopically assisted abdominal surgery were eligible to participate. Patients were randomly assigned either to the control group with $0.9 \%$ saline or to the experimental group with $0.04 \%$ polyhexanide solution [6].

\section{Outcomes}

In the RECIPE trial, SSI was defined according to the criteria by the Centers for Disease Control and Prevention within 30 days postoperatively (Table 1) [6]. Examination of the wound at least every second day, regularly dressing changes, and decision, if SSI was present, were performed

Table 1 Definition of surgical site infection (SSI) according to Center for Disease Control [16]

\begin{tabular}{|c|c|}
\hline uperncial incisional SSI & $\begin{array}{l}\text { Infection occurs within } 30 \text { days after the operation } \\
\text { AND } \\
\text { Involves only skin and subcutaneous tissue of the incision } \\
\text { AND patient has at least one of the following: } \\
\text { 1. Purulent drainage from the superficial incision } \\
\text { 2. Organisms isolated from an aseptically obtained culture of fluid or tissue from the superficial incision } \\
\text { 3. At least one of the following symptoms: localized pain or tenderness; localized swelling; erythema; or heat and the } \\
\text { superficial incision is deliberately opened by a surgeon unless incision is culture-negative } \\
\text { 4. Diagnosis of superficial incisional SSI by the surgeon }\end{array}$ \\
\hline Deep incisional SSI & $\begin{array}{l}\text { Infection occurs within } 30 \text { days after the operation and the infection appears to be related to the operation } \\
\text { AND } \\
\text { Involves deep soft tissue of the incision (e.g., fascial and muscle layers) } \\
\text { AND patient has at least one of the following: } \\
\text { 1. Purulent drainage from the deep incision but not from the organ/space component of the surgical site } \\
\text { 2. A deep incision spontaneously dehisces or is deliberately opened by a surgeon when the patient has at least one of } \\
\text { the following symptoms: fever }\left(>38^{\circ} \mathrm{C}\right) \text {; localized pain or tenderness; unless the site is culture-negative } \\
\text { 3. An abscess or other evidence of infection involving the deep incision is found on direct examination, during reop- } \\
\text { eration, or by histopathologic or radiologic examination } \\
\text { 4. Diagnosis of a deep incisional SSI by a surgeon }\end{array}$ \\
\hline Organ/space SSI & $\begin{array}{l}\text { Infection occurs within } 30 \text { days after the operation and the infection appears to be related to the operation } \\
\text { AND } \\
\text { Involves any part of the body deeper than fascial/muscle layers that were opened or manipulated during an operation } \\
\text { AND patient has at least one of the following: } \\
\text { 1. Purulent drainage from a drain that was placed into the organ/space } \\
\text { 2. Organisms isolated from an aseptically obtained culture of fluid or tissue in the organ/space } \\
\text { 3. An abscess or other evidence of infection involving the organ/space is found on direct examination, during reopera- } \\
\text { tion or by histopathologic or radiologic examination } \\
\text { 4. Diagnosis of an organ/space SSI by a surgeon }\end{array}$ \\
\hline
\end{tabular}


on the surgical ward by attending surgeons. To evaluate SSIs after discharge, an interview by telephone was conducted at least 30 days postoperatively. Patients were asked whether the wound was closed or secondary healing and whether inpatient or outpatient medical treatment of the SSI was required. In case of uncertain wound sites, an appointment in our outpatient department was arranged for the patient. We classified SSI in superficial, deep, and organ/space SSI according to CDC (Table 1) [6]. An intraabdominal abscess was counted as organ/space SSI (grade 3) when it occurred in close proximity to the surgical incision.

The endpoints of this post hoc analysis included the overall inpatient costs. The cost analysis referred to inpatient treatment. Data on costs were collected with the help of the tool of our corporate controlling team. The calculated costs of our study population only refer to the department for general and visceral surgery of Charité Berlin, Campus Benjamin Franklin, where the study was conducted. The calculation of costs is based on the official guidelines of the German Institute for remuneration in hospitals (InEK) for the calculation of diagnosis-related groups in Germany. The German Institute for remuneration in hospitals (InEK) sets these guidelines to ensure that the calculation of costs is comparable between all participating hospitals in Germany [8]. The tool of our corporate controlling team is a graphic display which outlines the calculation of costs and the comparison of proceeds and costs. This tool calculated the exact inpatient costs based on the case number of every single patient. These included overall costs of hospital treatment, surgery costs, costs on surgical ward, medication costs, laboratory costs, and costs of diagnostic procedures. Overall inpatient costs consisted of all categories that are depicted in Table 2 . Surgery costs were mainly referring to cutting-suture time and time of anesthesia. Surgery costs also involved costs for revision surgery. Costs for medical material and drugs used in the operation room are included. In case of readmission within 30 days postoperatively, costs were added to the primary case number. In the case of reoperation surgery, costs of the second operation were added to the primary case number. Patients were interviewed by telephone at 30 days or greater postoperatively. Satisfaction with wound cosmesis was graded on a numeric analog scale (NAS) from 0-3 (not content) over 4-7 (moderately content) to 8-10 (very content). The parameter pain was assessed in the area of the scar or secondarily healing wound 30 days postoperatively. The pain was recorded on NAS ranging from 0 (no pain) to 10 (strongest pain imaginable).

\section{Statistical analysis}

Categorical variables of the primary outcome were analyzed with cross-tabulation and chi-square tests. For quantitative outcomes, statistical group comparisons were performed using the $t$-test for independent samples. Due to the skewed distribution of some of the quantitative variables, group differences were analyzed by Mann-Whitney $U$ test or Kruskal-Wallis test. Additional parameters were depicted according to their scale and distribution with absolute and relative frequencies for categorical parameters and mean, standard deviation (SD), median, and interquartile range (IQR) for quantitative parameters; $p$-values $\leq 0.05$ were considered as statistically significant. Statistical analysis was carried out using IBM SPSS Statistics 25® (IBM, Armonk, NY, USA).

\section{Results}

\section{Patient characteristics}

In the RECIPE trial, 456 patients were recruited and 393 (86.2\%) completed the follow-up 30 days postoperatively [6]. Patients of this post hoc analysis had an average age of $58.3 \pm 16.2$ years. Overall, there were 154 (39.2\%) female and $239(60.8 \%)$ male patients. There was neither a difference in the duration of surgery nor in the organ site of the conducted operation between patients with and without SSI. Right- or left-sided hemicolectomy was performed in $23.9 \%$, low anterior rectum resection in $13.8 \%$, and colectomy or proctocolectomy in $13.0 \%$ (Table 3 ).

\section{Cost analysis}

The overall inpatient costs for patients with SSI were 16.685 $€ ; 19.703$ USD median (IQR $21.638 € ; 25.552$ USD) compared to $11.235 € ; 13.267$ USD median (IQR $11.564 €$; 13.656 USD) for patients without SSI $(p<0.001)$. Surgery costs differed in patients with SSI (6.664 $€ ; 7.870$ USD) to patients without SSI (5.040 €; 5.952 USD) $(p=0.001)$. Regarding costs on surgical ward, the occurrence of SSI was more expensive (8.404 €; 9.924 USD vs. $4.690 € ; 5.538$ USD; $p<0.001)$. The same refers to medication costs (663 $€ ; 783$ USD vs. $306 €$ (361 USD; $p<0.001)$ and laboratory costs (965 $€ ; 1.140$ USD vs. $592 € ; 699$ USD; $p=0.005$ ) (Table 4). Additional costs directly caused by SSI were identified by excluding patients with severe postoperative complications (grades 3-5 according to Clavien-Dindo) in a supplementary analysis. Overall inpatient costs for patients with SSI without severe complication were $11.908 € ; 14.038$ USD median (IQR $4.933 € ; 5.816$ USD) vs. $9.354 € ; 11.027$ USD median (IQR $6.306 € ; 7.434$ USD) patients without SSI $(p=0.006)$. Costs on the surgical ward were $5.715 € ; 6.737$ USD median (IQR $4.568 € ; 5.385$ USD) for patients with SSI vs. $3.707 € ; 4.370$ USD median (IQR $2.988 € ; 3.523$ USD) for patients without SSI $(p=0.001)$. 
Table 2 Composition of cost analysis

Costs of ward surgery costs, medication costs, laboratory costs, costs of diagnostic procedures; ${ }^{*}$ PPR $=$ " "Pflëgepeerssonalregelung" $=$ regulation" of the nursing staft; overall costs consist of all depicted categories

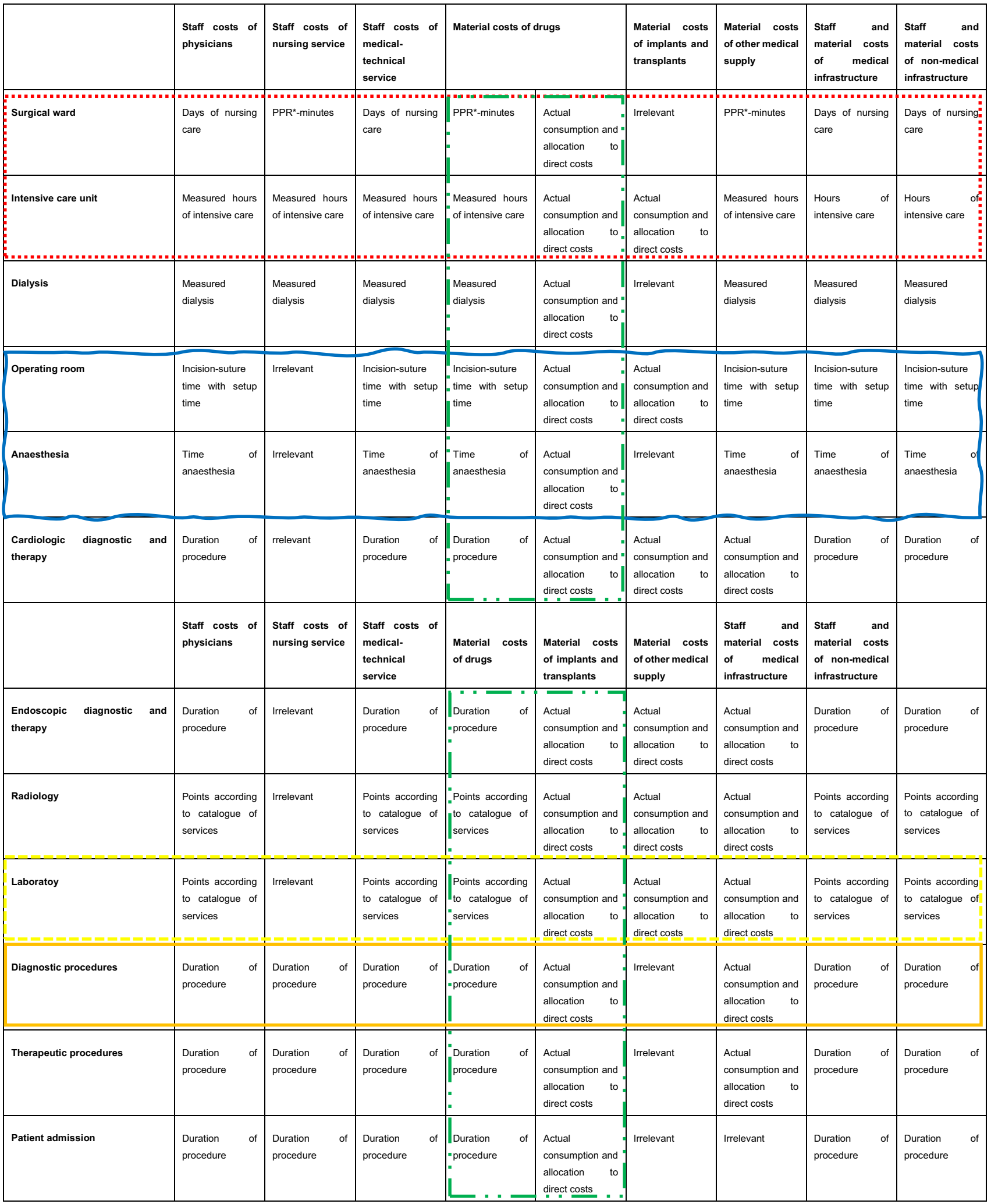


Table 3 Baseline and surgical characteristics

\begin{tabular}{lllll}
\hline & SSI $(n=111)$ & No SSI $(n=282)$ & Total $(n=393)$ & $p$-value \\
\hline Sex & & & & $0.91^{*}$ \\
Female & $43(38.7 \%)$ & $111(39.4 \%)$ & $154(39.2 \%)$ & \\
Male & $68(61.3 \%)$ & $171(60.6 \%)$ & $239(60.8 \%)$ & \\
Age (years; mean $\pm \mathrm{SD})$ & $56.6 \pm 16.8$ & $59.1 \pm 15.9$ & $58.3 \pm 16.2$ & $0.17+$ \\
BMI $\left(\mathrm{kg} / \mathrm{m}^{2}\right.$, mean $\left.\pm \mathrm{SD}\right)$ & $24.9 \pm 4.7$ & $25.3 \pm 4.5$ & $25.2 \pm 4.6$ & $0.48+$ \\
Duration of surgery $(\mathrm{min} ;$ mean $\pm \mathrm{SD})$ & $253.3 \pm 119.8$ & $249.8 \pm 123.0$ & $250.8 \pm 121.9$ & $0.80+$ \\
Organ site/type of operation & & & & $0.21^{*}$ \\
Esophagus resection & $4(3.6 \%)$ & $15(5.3 \%)$ & $19(4.8 \%)$ & \\
Stomach resection & $9(8.1 \%)$ & $16(5.7 \%)$ & $25(6.4 \%)$ & \\
Liver resection & $9(8.1 \%)$ & $29(10.2 \%)$ & $38(9.7 \%)$ & \\
Pancreas resection & $5(4.5 \%)$ & $18(6.4 \%)$ & $23(5.8 \%)$ & \\
Small bowel resection & $22(19.8 \%)$ & $27(9.6 \%)$ & $49(12.5 \%)$ & \\
Ileocecal resection & $4(3.6 \%)$ & $15(5.3 \%)$ & $19(4.8 \%)$ & \\
Right- or left-sided hemicolectomy & $26(23.4 \%)$ & $68(24.1 \%)$ & $94(23.9 \%)$ & \\
Low anterior resection & $15(13.5 \%)$ & $39(13.9 \%)$ & $54(13.8 \%)$ & \\
Colectomy or proctocolectomy & $14(12.6 \%)$ & $37(13.1 \%)$ & $51(13.0 \%)$ & \\
Multivisceral resection & $1(0.9 \%)$ & $5(1.8 \%)$ & $6(1.5 \%)$ & \\
Others & $2(1.8 \%)$ & $13(4.6 \%)$ & $15(3.8 \%)$ & \\
\hline
\end{tabular}

Data are $n(\%)$ or mean $\pm \mathrm{SD} ; S D$, standard deviation; SSI, surgical site infection; BMI, body mass index; $\min$, minutes; *chi-square test; $\uparrow t$-test for independent samples
Overall inpatient costs for patients who were irrigated with saline in the RECIPE trial were $12.056 € ; 14.237$ USD median (IQR 13.612 €; 16.074 USD) vs. $12.793 € ; 15.107$ USD median (IQR 12.085 $€$; 14.271 USD) in the polyhexanide group $(p=0.52)$. Surgery costs amounted to $5.156 €$; 6.089 USD) in the saline and $5.596 €(6.608$ USD) in the polyhexanide group $(p=0.53)$.

Surgery costs varied depending on the performed procedure. For example, costs for esophagus resection were $11.586 € ; 13.682$ USD median, for pancreas resection 8.473 $€ ; 10.006$ USD median, and for right- or left-sided hemicolectomy $4.055 € ; 4.789$ USD median; $p<0.001$ (Table 5).

\section{Postoperative outcome}

Overall, we recorded 111 (28.2\%) SSIs. Sixty-six (59.5\%) of SSI were detected during inpatient treatment and 45 (40.5\%) occurred within 30 days postoperatively. Data about the satisfaction with the cosmetic result 30 days postoperatively were documented in 318 patients. Eighteen patients with SSI $(16.2 \%)$ and twelve patients without SSI (4.3\%) were not content $(p<0.001)$ (Table 6).

Seventy-five $(67.6 \%)$ patients with SSI required medical treatment of SSI again after discharge. Inpatient medical treatment after discharge was necessary in six (5.4\%) patients and outpatient treatment in $69(62.2 \%)$ patients with SSI $(p<0.001)$.

The total length of hospital stay including readmission was 18 days median (patients with SSI) compared to 12 days median (patients without SSI) $(p<0.001)$ [6]. In the group with SSI, postoperative pain at the scar 30 days postoperatively was rated $1.3 \pm 1.7 \mathrm{SD}$ on average on NAS compared to $0.6 \pm 1.4 \mathrm{SD}$ in the group without SSI $(p<0.001)(6)$. Patients without SSI complained less often about postoperative pain at the scar than patients with SSI: $71.3 \%$ vs. $41.4 \%$ had no pain $(p<0.001)[6]$.

\section{Discussion}

SSI is one of the most frequent complications in visceral surgery. Still, data on the economic impact of SSI on the healthcare system in Germany and on patients' quality of life is rare. To our knowledge, this analysis is the first detailed economic evaluation of inpatient healthcare costs based on the tool of the corporate controlling team of the surgical department of Charité - Universitätsmedizin Berlin. Overall inpatient costs were higher in patients with SSI after elective laparotomy. SSI led to more postoperative pain and less satisfaction with the cosmetic result of the operation 30 days postoperatively.

This post hoc analysis was an integral part of the monocentric randomized controlled RECIPE trial with 456 patients that investigated the benefits of antiseptic intraoperative wound irrigation on SSI in visceral surgery. Healthcare costs were evaluated using the tool of our corporate controlling team based on the G-DRG system. This tool calculates the exact costs based on the case number of every single 
Table 4 Cost analysis of SSI

\begin{tabular}{|c|c|c|c|c|}
\hline & $\begin{array}{l}\text { SSI } \\
(n=103)\end{array}$ & $\begin{array}{l}\text { No SSI } \\
(n=251)\end{array}$ & $\begin{array}{l}\text { Total } \\
(n=354)\end{array}$ & $p$-value* \\
\hline Overall inpatient costs & & & & $<0.001+$ \\
\hline Median & $\begin{array}{l}16.685 € \\
(19.703 \text { USD) }\end{array}$ & $\begin{array}{l}11.235 € \\
(13.267 \text { USD) }\end{array}$ & $\begin{array}{l}12.658 € \\
(14.948 \text { USD) }\end{array}$ & \\
\hline $\mathrm{IQR}$ & $\begin{array}{l}21.638 € \\
(25.552 \text { USD) }\end{array}$ & $\begin{array}{l}11.564 € \\
(13.656 \text { USD) }\end{array}$ & $\begin{array}{l}14.140 € \\
(16.742 \text { USD) }\end{array}$ & \\
\hline Q25 & $\begin{array}{l}10.626 € \\
(12.581 \text { USD) }\end{array}$ & $\begin{array}{l}7.521 € \\
(8.905 \text { USD) }\end{array}$ & $\begin{array}{l}8.259 € \\
(9.779 \text { USD) }\end{array}$ & \\
\hline Q75 & $\begin{array}{l}32.264 € \\
(38.200 \text { USD) }\end{array}$ & $\begin{array}{l}19.085 € \\
(22.597 \text { USD) }\end{array}$ & $\begin{array}{l}22.399 € \\
(26.520 \text { USD) }\end{array}$ & \\
\hline Surgery costs & & & & $0.001+$ \\
\hline Median & $\begin{array}{l}6.664 € \\
(7.870 \text { USD) }\end{array}$ & $\begin{array}{l}5.040 € \\
(5.952 \text { USD) }\end{array}$ & $\begin{array}{l}5.416 € \\
(6.396 \text { USD) }\end{array}$ & \\
\hline $\mathrm{IQR}$ & $\begin{array}{l}6.550 € \\
\text { ( } 7.735 \text { USD) }\end{array}$ & $\begin{array}{l}3.992 € \\
(4.714 \text { USD) }\end{array}$ & $\begin{array}{l}4.865 € \\
(5.760 \text { USD) }\end{array}$ & \\
\hline Q25 & $\begin{array}{l}4.132 € \\
(4.892 \text { USD) }\end{array}$ & $\begin{array}{l}3.420 € \\
(4.049 \text { USD) }\end{array}$ & $\begin{array}{l}3.557 € \\
(4.211 \text { USD) }\end{array}$ & \\
\hline Q75 & $\begin{array}{l}10.682 € \\
(12.647 \text { USD) }\end{array}$ & $\begin{array}{l}7.412 € \\
(8.776 \text { USD) }\end{array}$ & $\begin{array}{l}8.423 € \\
(9.973 \text { USD) }\end{array}$ & \\
\hline Costs on surgical ward & & & & $<0.001+$ \\
\hline Median & $\begin{array}{l}8.404 € \\
(9.924 \text { USD) }\end{array}$ & $\begin{array}{l}4.690 € \\
(5.538 \text { USD) }\end{array}$ & $\begin{array}{l}5.533 € \\
(6.534 \text { USD) }\end{array}$ & \\
\hline $\mathrm{IQR}$ & $\begin{array}{l}15.099 € \\
(17.830 \text { USD) }\end{array}$ & $\begin{array}{l}6.456 € \\
\text { ( } 7.624 \text { USD) }\end{array}$ & $\begin{array}{l}8.099 € \\
(9.589 \text { USD) }\end{array}$ & \\
\hline Q25 & $\begin{array}{l}4.430 € \\
(5.245 \text { USD) }\end{array}$ & $\begin{array}{l}3.067 € \\
(3.631 \text { USD) }\end{array}$ & $\begin{array}{l}3.305 € \\
\text { (3.913 USD) }\end{array}$ & \\
\hline \multicolumn{5}{|l|}{ Costs on surgical ward } \\
\hline Q75 & $\begin{array}{l}19.529 € \\
(23.122 \text { USD) }\end{array}$ & $\begin{array}{l}9.523 € \\
(11.275 \text { USD) }\end{array}$ & $\begin{array}{l}11.403 € \\
(13.501 \text { USD) }\end{array}$ & \\
\hline Medication costs & & & & $<0.001+$ \\
\hline Median & $\begin{array}{l}663 € \\
(783 \text { USD) }\end{array}$ & $\begin{array}{l}306 € \\
(361 \text { USD) }\end{array}$ & $\begin{array}{l}371 € \\
(438 \text { USD) }\end{array}$ & \\
\hline $\mathrm{IQR}$ & $\begin{array}{l}1.798 € \\
\text { (2.123 USD) }\end{array}$ & $\begin{array}{l}663 € \\
\text { (783 USD) }\end{array}$ & $\begin{array}{l}1.152 € \\
(1.364 \text { USD) }\end{array}$ & \\
\hline Q25 & $\begin{array}{l}273 € \\
\text { (323 USD) }\end{array}$ & $\begin{array}{l}179 € \\
(212 \text { USD) }\end{array}$ & $\begin{array}{l}191 € \\
(226 \text { USD) }\end{array}$ & \\
\hline Q75 & $\begin{array}{l}2.071 € \\
(2.452 \text { USD) }\end{array}$ & $\begin{array}{l}842 € \\
\text { ( } 997 \text { USD) }\end{array}$ & $\begin{array}{l}1.344 € \\
(1.591 \text { USD) }\end{array}$ & \\
\hline Laboratory costs & & & & $0.005+$ \\
\hline Median & $\begin{array}{l}965 € \\
(1.140 \text { USD) }\end{array}$ & $\begin{array}{l}592 € \\
(699 \text { USD) }\end{array}$ & $\begin{array}{l}661 € \\
(781 \text { USD) }\end{array}$ & \\
\hline IQR & $\begin{array}{l}1.742 € \\
\text { (2.057 USD) }\end{array}$ & $\begin{array}{l}988 € \\
(1.167 \text { USD) }\end{array}$ & $\begin{array}{l}1.079 € \\
(1.278 \text { USD) }\end{array}$ & \\
\hline Q25 & $\begin{array}{l}330 € \\
(391 \mathrm{USD})\end{array}$ & $\begin{array}{l}286 € \\
\text { (339 USD) }\end{array}$ & $\begin{array}{l}296 € \\
(350 \text { USD) }\end{array}$ & \\
\hline Q75 & $\begin{array}{l}2.072 € \\
(2.453 \text { USD) }\end{array}$ & $\begin{array}{l}1.275 € \\
(1.510 \text { USD) }\end{array}$ & $\begin{array}{l}1.375 € \\
(1.628 \text { USD) }\end{array}$ & \\
\hline Costs of diagnostic procedures & & & & 0.13 \\
\hline Median & $\begin{array}{l}60 € \\
(71 \mathrm{USD})\end{array}$ & $\begin{array}{l}33 € \\
\text { ( } 39 \text { USD) }\end{array}$ & $\begin{array}{l}40 € \\
\text { (47 USD) }\end{array}$ & \\
\hline IQR & $\begin{array}{l}242 € \\
\text { (286 USD) }\end{array}$ & $\begin{array}{l}103 € \\
(122 \text { USD) }\end{array}$ & $\begin{array}{l}143 € \\
(169 \text { USD) }\end{array}$ & \\
\hline \multicolumn{5}{|l|}{ Costs of diagnostic procedures } \\
\hline Q25 & $\begin{array}{l}9 € \\
\text { (11 USD) }\end{array}$ & $\begin{array}{l}9 € \\
\text { (11 USD) }\end{array}$ & $\begin{array}{l}9 € \\
\text { (11 USD) }\end{array}$ & \\
\hline Q75 & $\begin{array}{l}251 € \\
(297 \text { USD) }\end{array}$ & $\begin{array}{l}111 € \\
(131 \text { USD) }\end{array}$ & $\begin{array}{l}152 € \\
(180 \text { USD) }\end{array}$ & \\
\hline
\end{tabular}

Data are $€$ and USD; IQR, interquartile range; $Q 25,0.25$ quartile; $Q 75,0.75$ quartiles; exchange rate from $€$ in USD based on $11 / 12 / 2020 ; S S I$, surgical site infection; *Mann-Whitney $U$ test; $\uparrow p \leq 0.05$ 
Table 5 Surgery costs depending on the procedure

\begin{tabular}{lll}
\hline & Surgery costs $(n=392)$ & $p$-value* \\
\hline Surgical procedure & $<0.001+$ \\
Esophagus resection & $11.586 €(13.682$ USD $)$ \\
Stomach resection & $7.098 €(8.382$ USD $)$ \\
Major liver resection & $6.582 €(7.773$ USD $)$ \\
Minor liver resection & $4.978 €(5.879$ USD $)$ \\
Pancreas resection & $8.473 €(10.006$ USD $)$ \\
Small bowel resection & $3.787 €(4.472$ USD $)$ \\
Ileocecal resection & $3.379 €(3.990$ USD $)$ \\
Right- or left-sided hemicolec- & $4.055 €(4.789$ USD $)$ \\
$\quad$ tomy & \\
Low anterior resection & $5.641 €(6.661$ USD $)$ \\
Abdominoperineal excision & $9.459 €(11.170$ USD $)$ \\
Colectomy, proctocolectomy, & $6.646 €(7.848$ USD $)$ \\
proctectomy, and ileoanal & \\
pouch & \\
Multivisceral resection and & $3.547 €(4.189$ USD) \\
others &
\end{tabular}

Data are median, $€$ and USD; exchange rate from $€$ in USD based on 11/12/2020; *Kruskal-Wallis test; $+p \leq 0.05$

patient which provides accurate cost estimates to understand the true burden of SSI. In case of readmission within 30 days postoperatively, the costs were added to the primary case number.

The overall median inpatient costs for patients with SSI accounted for $16.685 €$ (19.703 USD) and were therefore higher than for patients without SSI (11.235€; 13.267 USD). Regarding the subcategories surgery costs, costs of the surgical ward, medication, and laboratory costs, all of these were more expensive in the group with SSI. As stated previously in the RECIPE trial, the length of hospital stay was longer in patients with SSI [6]. This is one factor possibly increasing costs on a surgical ward for patients with SSI and costs for medication and laboratory. One factor that might have influenced the higher costs of patients with SSI in this analysis is the concomitant incidence of severe postoperative complications (grades 3-5 according to Clavien-Dindo). Nearly $29 \%$ of patients with SSI required reoperation in general anesthesia, not due to SSI. A comparison of patients with SSI but no further complication and patients without SSI revealed that overall inpatient costs were approximately $2.500 €$ (3.000 USD) higher when SSI occurred. Eighty percent of the increase in costs was caused by costs on a surgical ward.

Previous trials also presented increasing healthcare costs due to SSI. In a single-center, case matched followup study, Kirkland et al. [9] showed that the median direct costs of hospitalization were 7.531 USD for patients with SSI and 3.844 USD for patients without SSI. The mean additional cost per patient with SSI was $£ 10.523$ (13.864
USD) calculated from actual resources used by each patient in a British surveillance program in colorectal surgery [10]. Economic data in our study were collected in a prospective randomized controlled setting. The cost assessment tool was not based on any economic model such as in some of the aforementioned studies. Our tool provides accurate data based on every patient's individual hospital case.

In this analysis, the impact of SSI on the 30-day morbidity of patients was clearly shown. The total length of hospital stay was 6 days longer in the median when SSI occurred during inpatient treatment, as described previously in the RECIPE trial [6]. Prolongation of hospital stay because of SSI was also seen in a single-center, case-matched followup study by Kirkland et al. [9]. A systematic review of six European countries outlined that SSI was associated with elevated healthcare costs and prolonged hospitalization [11]. Pinkney et al. [12] reported an $11 \%$ reduction in healthrelated quality of life 30 days postoperatively in patients with SSI after laparotomy. A systematic review by Gheorghe et al. [13] again identified a lack of studies that investigate the impact of SSI particularly in abdominal surgery on quality of life.

To our knowledge, this is the first study to evaluate the impact of SSI on subjective parameters such as pain and satisfaction with the cosmetic result. Patients with SSI complained more often about pain at the scar 30 days postoperatively than patients without SSI. They rated higher on the 10-point numeric analogous scale for pain. Additionally, patients who developed SSI were less content with the cosmetic result of the scar 30 days postoperatively. It must be recognized that postoperative pain and satisfaction with the cosmetic result are two subjective parameters.

The overall detected SSI rate of $28 \%$ in elective visceral surgery is above the average SSI rate of other trials. The German National Reference Center for the surveillance of nosocomial infections depicts nearly $11 \%$ of SSI following colorectal surgery referring to patients during the period of hospitalization [14]. The comprehensive detection of SSI by thorough and regular examination on the ward and the exact capturing of outpatient SSI are two main reasons for the high rate of SSI in our study. Data concerning only hospitalized patients might not be representative. Other trials focusing on SSI as a primary endpoint found similarly high rates of SSI. The overall rate of SSI was $21.4 \%$ in a German multicenter randomized controlled trial focusing on circular plastic wound edge protectors in laparotomy [15]. A British multicenter randomized trial addressing the impact of wound edge protection devices on SSI reported a similarly high rate of $25 \%$ SSI [12].

In the RECIPE trial, evidence is provided that intraoperative subcutaneous wound irrigation with antiseptic polyhexanide solution reduces SSI in elective laparotomies compared to saline [6]. One research question was whether median 
Table 6 Impact of SSI on postoperative outcome

\begin{tabular}{|c|c|c|c|c|}
\hline & $\begin{array}{l}\text { SSI } \\
(n=111)\end{array}$ & $\begin{array}{l}\text { No SSI } \\
(n=282)\end{array}$ & $\begin{array}{l}\text { Total } \\
(n=393)\end{array}$ & $p$-value \\
\hline Satisfaction with cosmetic result & & & & $<0.001 * \S$ \\
\hline Not content $(0-3)$ & $\begin{array}{l}18 \\
(16.2 \%)\end{array}$ & $\begin{array}{l}12 \\
(4.3 \%)\end{array}$ & $\begin{array}{l}30 \\
(7.6 \%)\end{array}$ & \\
\hline Moderately content (4-7) & $\begin{array}{l}36 \\
(32.4 \%)\end{array}$ & $\begin{array}{l}84 \\
(29.8 \%)\end{array}$ & $\begin{array}{l}120 \\
(30.5 \%)\end{array}$ & \\
\hline Very content $(8-10)$ & $\begin{array}{l}20 \\
(18.0 \%)\end{array}$ & $\begin{array}{l}148 \\
(52.5 \%)\end{array}$ & $\begin{array}{l}168 \\
(42.7 \%)\end{array}$ & \\
\hline Missing data & $\begin{array}{l}37 \\
(33.3 \%)\end{array}$ & $\begin{array}{l}38 \\
(13.5 \%)\end{array}$ & $\begin{array}{l}75 \\
(19.1 \%)\end{array}$ & \\
\hline Medical treatment of SSI after discharge & $\begin{array}{l}75 \\
(67.6 \%)\end{array}$ & $\begin{array}{l}0 \\
(0 \%)\end{array}$ & $\begin{array}{l}75 \\
(19.1 \%)\end{array}$ & $<0.001 * \S$ \\
\hline Inpatient treatment after discharge & $\begin{array}{l}6 \\
(5.4 \%)\end{array}$ & $\begin{array}{l}0 \\
(0 \%)\end{array}$ & $\begin{array}{l}6 \\
(1.5 \%)\end{array}$ & $<0.001 * \S$ \\
\hline Outpatient treatment after discharge & $\begin{array}{l}69 \\
(62.2 \%)\end{array}$ & $\begin{array}{l}0 \\
(0 \%)\end{array}$ & $\begin{array}{l}69 \\
(17.6 \%)\end{array}$ & $<0.001 * \S$ \\
\hline Missing data & $\begin{array}{l}6 \\
(5.4 \%)\end{array}$ & $\begin{array}{l}9 \\
(3.2 \%)\end{array}$ & $\begin{array}{l}15 \\
(3.8 \%)\end{array}$ & \\
\hline Postoperative pain on NAS (mean \pm SD) & $1.3 \pm 1.7$ & $0.6 \pm 1.4$ & $0.8 \pm 1.5$ & $<0.001^{*} \ddagger$ \\
\hline Postoperative pain on NAS & & & & $<0.001 * \S$ \\
\hline None $(0)$ & $\begin{array}{l}46 \\
(41.4 \%)\end{array}$ & $\begin{array}{l}201 \\
(71.3 \%)\end{array}$ & $\begin{array}{l}247 \\
(62.8 \%)\end{array}$ & \\
\hline Mild (1-3) & $\begin{array}{l}48 \\
(43.2 \%)\end{array}$ & $\begin{array}{l}64 \\
(22.7 \%)\end{array}$ & $\begin{array}{l}112 \\
(28.5 \%)\end{array}$ & \\
\hline Moderate to strong (4-10) & $\begin{array}{l}4 \\
(3.6 \%)\end{array}$ & $\begin{array}{l}4 \\
(1.4 \%)\end{array}$ & $\begin{array}{l}8 \\
(2.0 \%)\end{array}$ & \\
\hline Missing data & $\begin{array}{l}13 \\
(11.7 \%)\end{array}$ & $\begin{array}{l}13 \\
(4.6 \%)\end{array}$ & $\begin{array}{l}26 \\
(6.6 \%)\end{array}$ & \\
\hline Total length of hospital stay (days; median) & 18.0 & 12.0 & 14.0 & $<0.001 *+$ \\
\hline $\begin{array}{l}\text { Severe postoperative complication (Clavien-Dindo } \\
\text { grades 3-5) until discharge }\end{array}$ & $\begin{array}{l}48 \\
(43.2 \%)\end{array}$ & $\begin{array}{l}67 \\
(23.8 \%)\end{array}$ & $\begin{array}{l}115 \\
(29.3 \%)\end{array}$ & $<0.001 * \S$ \\
\hline Reoperation in general anesthesia total & $\begin{array}{l}52 \\
(46.8 \%)\end{array}$ & $\begin{array}{l}59 \\
(20.9 \%)\end{array}$ & $\begin{array}{l}111 \\
(28.2 \%)\end{array}$ & $<0.001 * \S$ \\
\hline Reoperation due to SSI and fascia dehiscence & $\begin{array}{l}20 \\
(18.0 \%)\end{array}$ & $\begin{array}{l}11 \\
(3.9 \%)\end{array}$ & $\begin{array}{l}9 \\
(2.3 \%)\end{array}$ & \\
\hline Reoperation not due to SSI & $\begin{array}{l}32 \\
(28.8 \%)\end{array}$ & $\begin{array}{l}48 \\
(17.0 \%)\end{array}$ & $\begin{array}{l}102 \\
(25.9 \%)\end{array}$ & \\
\hline
\end{tabular}

Data are $n(\%)$ or median or mean $\pm \mathrm{SD} ; S S I$, surgical site infection; ${ }^{*} p \leq 0.05$; †Mann-Whitney $U$ test; $N A S$, numerical analogous scale; $S D$, standard deviation; $\ddagger t$-test for independent samples; §chi-square test; the number of patients differs between the categories because follow-up was not accomplished by all patients

inpatient costs were cheaper in the group irrigated with polyhexanide. The price of $250 \mathrm{ml}$ of antiseptic $0.04 \%$ polyhexanide solution (Serasept $2 ®)$ is currently $4.93 €$ (5.52 USD) in Germany in an inpatient setting [6]. The price of $250 \mathrm{ml}$ of $0.9 \%$ saline is currently $1.05 €$ (1.14 USD) in Germany. There was no difference in median overall inpatient costs between the two irrigation solutions. Total inpatient costs were probably more influenced by even more severe postoperative complications or patients' comorbidities, showing the cost effect of the irrigation solution.
Several potential limitations of the trial must be taken into account. First, this was a monocenter randomized trial with inherent limitations. Perioperative settings, operative procedures, and patient characteristics may vary from the ones in other nonacademic German or international institutions. The calculated costs of our study population only refer to the department for general and visceral surgery of Charité Berlin, Campus Benjamin Franklin, where the study was conducted. Second, it should be noted that costs caused by SSI in the outpatient sector are not depicted by this trial. Nearly $41 \%$ of SSI in this trial occurred after discharge. Wounds healing by secondary intent require 
outpatient wound care with regularly dressing changes which additionally increase healthcare costs for patients with SSI. So it is possible that the true economic burden of SSI is underestimated. Tanner et al. [10] showed in a post-discharge surveillance program of SSI that costs for wound care after discharge accounted for $15 \%$ of the total costs. Third, there was no clinical examination 30 days postoperatively, leaving the chance of missing some SSI or capturing some delayed wound healings as SSI which did not fulfill the CDC criteria. We strictly complied with the follow-up time of 30 days postoperatively and interviewed the patients by telephone [6]. Fourth, a variety of surgical procedures was included in the RECIPE trial as all elective laparotomies or laparoscopically assisted surgeries were eligible for inclusion. There was no difference in the rate of SSI depending on the organ site. A trend towards more SSI in small bowel resection was shown. The subgroups of surgical procedures might be underpowered, and therefore, no difference in the rate of SSI was found in our trial.

Taken these limitations into account, this post hoc analysis of a large-scale prospective randomized trial with comprehensive cost analysis showed a marked increase in inpatient costs for patients with SSI. Furthermore, patients with SSI reported more pain and worse cosmetic results in postoperative 30-day follow-up.

\section{Conclusion}

This post hoc analysis of the randomized controlled RECIPE trial provided evidence that SSI has a major impact on patients' postoperative course. Inpatient healthcare costs due to SSI are increased. Therefore, the prevention of SSI is crucial. Overall costs for intraoperative wound irrigation with saline were comparable with polyhexanide.

\footnotetext{
Authors' contributions Dr. med. Rahel M. Strobel, Dr. rer. medic. Marja Leonhardt, Frank Förster, Dr. rer. nat. Konrad Neumann, and Priv.-Doz. Dr. med. Johannes C. Lauscher: study conception and design, acquisition of data, analysis and interpretation of data, drafting of the manuscript, and critical revision of the manuscript. Dr. med. Leonard A. Lobbes, Dr. med. Claudia Seifarth, Dr. med. Lucas D. Lee, Dr. med. Christian H. W. Schineis, Priv.-Doz. Dr. med. Carsten Kamphues, Priv.-Doz. Dr. med. Benjamin Weixler, and Prof. Dr. med. Martin E. Kreis: analysis and interpretation of data, drafting of the manuscript, and critical revision of the manuscript.
}

Funding Open Access funding enabled and organized by Projekt DEAL.

Data availability This trial is registered at http://www.ClinicalTrials. gov (ID: NCT04055233).

\section{Declarations}

Ethics approval The trial was conducted in accordance with the ethical principles of the Declaration of Helsinki and the principles of Good Clinical Practice (ICH-GCP E6). The study protocol was approved by the State Office for Health and Social Affairs Berlin (Study Protocol code RECIPE2014; EudraCT number: 2014-001551-22) and the Federal Institute for Drugs and Medical Devices.

Consent to participate Informed consent was obtained from all individual participants included in the study.

Consent for publication Consent for publication was obtained from all individual participants.

Conflict of interest Dr. med. Rahel M. Strobel is participant in the BIH-Charité Junior Scientist Program funded by the Charité -Universitätsmedizin Berlin and the Berlin Institute of Health.

Open Access This article is licensed under a Creative Commons Attribution 4.0 International License, which permits use, sharing, adaptation, distribution and reproduction in any medium or format, as long as you give appropriate credit to the original author(s) and the source, provide a link to the Creative Commons licence, and indicate if changes were made. The images or other third party material in this article are included in the article's Creative Commons licence, unless indicated otherwise in a credit line to the material. If material is not included in the article's Creative Commons licence and your intended use is not permitted by statutory regulation or exceeds the permitted use, you will need to obtain permission directly from the copyright holder. To view a copy of this licence, visit http://creativecommons.org/licenses/by/4.0/.

\section{References}

1. Smith RL, Bohl JK, McElearney ST, Friel CM, Barclay MM, Sawyer RG et al (2004) Wound infection after elective colorectal resection. Ann Surg 239(5):599-605 (discussion 605-607)

2. Diener MK, Knebel P, Kieser M, Schüler P, Schiergens TS, Atanassov V et al (2014) Effectiveness of triclosan-coated PDS Plus versus uncoated PDS II sutures for prevention of surgical site infection after abdominal wall closure: the randomised controlled PROUD trial. Lancet Lond Engl 384(9938):142-52

3. Gastmeier P, Brandt C, Sohr D, Babikir R, Mlageni D, Daschner F et al (April 2004) Postoperative Wundinfektionen nach stationären und ambulanten Operationen - Ergebnisse aus dem KrankenhausInfektions- Surveillance-System (KISS). Bundesgesundheitsblatt - Gesundheitsforschung - Gesundheitsschutz 4:339-344

4. Anderson DJ, Kirkland KB, Kaye KS, Thacker PA, Kanafani ZA, Auten G et al (July 2007) Underresourced hospital infection control and prevention programs: penny wise, pound foolish? Infect Control Hosp Epidemiol 28(7):767-773

5. Stone PW, Braccia D, Larson E (November 2005) Systematic review of economic analyses of health care-associated infections. Am J Infect Control 33(9):501-509

6. Strobel RM, Leonhardt M, Krochmann A, Neumann K, Speichinger F, Hartmann L et al (July 2020) Reduction of postoperative wound infections by antiseptica (RECIPE)?: a randomized controlled trial. Ann Surg 272(1):55-64

7. World Medical Association (2013) World Medical Association Declaration of Helsinki: ethical principles for medical research involving human subjects. JAMA 310(20):2191-4

Code availability Not applicable. 
8. Lungen M, Dredge B, Rose A, Roebuck C, Plamper E, Lauterbach $\mathrm{K}$ et al (2004) Using diagnosis-related groups. Eur J Health Econ $5(4): 287-9$

9. Kirkland KB, Briggs JP, Trivette SL, Wilkinson WE, Sexton DJ (November 1999) The impact of surgical-site infections in the 1990s: attributable mortality, excess length of hospitalization, and extra costs. Infect Control Hosp Epidemiol 20(11):725-730

10. Tanner J, Khan D, Aplin C, Ball J, Thomas M, Bankart J (July 2009) Post-discharge surveillance to identify colorectal surgical site infection rates and related costs. J Hosp Infect 72(3):243-250

11. Badia JM, Casey AL, Petrosillo N, Hudson PM, Mitchell SA, Crosby C (May 2017) Impact of surgical site infection on healthcare costs and patient outcomes: a systematic review in six European countries. J Hosp Infect 96(1):1-15

12 Pinkney TD, Calvert M, Bartlett DC, Gheorghe A, Redman $\mathrm{V}$, Dowswell G et al (2013) Impact of wound edge protection devices on surgical site infection after laparotomy: multicentre randomised controlled trial (ROSSINI Trial). BMJ 347:f4305

13. Gheorghe A, Moran G, Duffy H, Roberts T, Pinkney T, Calvert M (2015) Health utility values associated with surgical site infection: a systematic review. Value Health 18(8):1126-37

14. Nationales Referenzzentrum für Surveillance von nosokomialen Infektionen, Robert Koch-Institut. Modul OP-KISS,
Referenzdaten, Berlin 2020. [cited $20^{\text {th }}$ of April 2021] Available at: https://www.nrz-hygiene.de/fileadmin/nrz/module/op/201701_ 201912_OPRef.pdf. Accessed 29 Jan 2021

15. Mihaljevic AL, Schirren R, Özer M, Ottl S, Grün S, Michalski CW et al (2014) Multicenter double-blinded randomized controlled trial of standard abdominal wound edge protection with surgical dressings versus coverage with a sterile circular polyethylene drape for prevention of surgical site infections: a CHIR-Net trial (BaFO; NCT01181206). Ann Surg 260(5):730-7 (discussion 737-739)

16. National Healthcare Safety Network. Surgical Site Infection (SSI) Event. Atlanta: Centers for Disease Control and Prevention [Internet]. 2013 [cited $29^{\text {th }}$ of January 2019]. Available at: http://www. cdc.gov/nhsn/PDFs/pscManual/9pscSSIcurrent.pdf. Accessed 29 Jan 2021

Publisher's note Springer Nature remains neutral with regard to jurisdictional claims in published maps and institutional affiliations. 